\title{
Double face of stem cells in paediatrics: therapeutic applications of mesenchymal stem cells and threats from cancer stem cells
}

\author{
Podwójna twarz komórek macierzystych w pediatrii: zastosowania terapeutyczne \\ mezenchymalnych komórek macierzystych i zagrożenia rakowymi komórkami macierzystymi
}

\author{
${ }^{1}$ Houston Methodist Research Institute, Houston, Texas, USA \\ 2 Department of Surgery, Houston Methodist Hospital, Houston, Texas, USA \\ ${ }^{3}$ Department of Regenerative Medicine and Cell Biology, Military Institute of Hygiene and Epidemiology (WIHE), Warsaw, Poland \\ ${ }^{4}$ UnivRennes, UMR 6290, CNRS, Institute of Genetics and Development of Rennes (IGDR), Cell Cycle Group, Faculty of Medicine, Rennes, France \\ ${ }^{5}$ Department of Genetics, The University of Texas, M.D. Anderson Cancer Center, Houston, Texas, USA \\ Correspondence: Malgorzata Kloc, Houston Methodist Research Institute, 6670 Bertner Ave, Houston, TX 77030, USA, e-mail: mkloc@houstonmethodist.org; Jacek Z. Kubiak, UMR 6290, CNRS/UR1, IGDR, \\ Faculty of Medicine, 2 Ave. du Prof. Leon Bernard, 35043 Rennes cedex, France, e-mail: jacek.kubiak@univ-rennes1.fr
}

\begin{abstract}
Decades of research have shown that many, if not all, fully developed and differentiated organs and tissues contain a subpopulation of undifferentiated stem cells or progenitors of stem cells, which under natural or experimental conditions can self-renew and differentiate into specialised cells. These findings have opened countless possibilities of novel therapeutic applications for the treatment of adult and child diseases. The main sources of stem cells used in paediatric therapies are umbilical cord and umbilical cord blood, amniotic fluid, placenta, bone marrow, adipose tissue, urine, and induced pluripotent stem cells derived from the patient's cells. Here, we describe some of the paediatrically applicable stem cell therapies. We focus our attention on the therapeutic applications of mesenchymal stem cells in paediatric diseases. An important but negative effect of stem cell therapies is the risk of oncogenic potential of therapeutically applied stem cells. Under certain circumstances, these stem cells can lead to tumour development. In addition, the majority of adult and paediatric tumours contain a subpopulation of cancer stem cells which are privileged therapeutic targets for numerous paediatric cancers. In this article, we review these two opposite properties ("double face") of stem cells in general and paediatric medicine.
\end{abstract}

Keywords: mesenchymal stem cells (MSCs), cancer stem cells (CSCs), stem cells therapies, glioma stem cells (GSCs), leukaemia stem cells (LSCs)

Streszczenie Dziesięciolecia badań wykazały, że wiele, jeśli nie wszystkie, w pełni rozwinięte i zróżnicowane narządy i tkanki zawierają subpopulację niezróżnicowanych komórek macierzystych lub progenitorów komórek macierzystych, które w naturalnych lub eksperymentalnych warunkach mogą się odnawiać i różnicować w wyspecjalizowane komórki. Odkrycia te otwierają niezliczone możliwości nowatorskich zastosowań terapeutycznych w leczeniu chorób dorosłych i dzieci. Głównymi źródłami komórek macierzystych stosowanych w terapii pediatrycznej są pępowina i krew pępowinowa, płyn owodniowy, łożysko, szpik kostny, tkanka tłuszczowa, mocz oraz indukowane pluripotencjalne komórki macierzyste, pochodzące z komórek pacjenta. W artykule opisujemy niektóre przykłady zastosowania terapii komórkami macierzystymi w pediatrii. Skupiamy naszą uwagę na terapeutycznych zastosowaniach mezenchymalnych komórek macierzystych w chorobach pediatrycznych. Ważnym, ale negatywnym skutkiem terapii komórkami macierzystymi jest zagrożenie związane z potencjałem onkogennym terapeutycznie stosowanych komórek macierzystych. W pewnych okolicznościach te komórki macierzyste mogą indukować rozwój nowotworów. Ponadto większość nowotworów u pacjentów zarówno dorosłych, jak i pediatrycznych zawiera subpopulację rakowych komórek macierzystych, które są uprzywilejowanymi celami terapeutycznymi w przypadku licznych nowotworów u dzieci. W artykule dokonujemy przeglądu tych dwóch przeciwnych aspektów („podwójnej twarzy”) komórek macierzystych w medycynie pediatrycznej i ogólnej.

Słowa kluczowe: mezenchymalne komórki macierzyste (MSC), nowotworowe komórki macierzyste (CSC), terapie komórkami macierzystymi, komórki macierzyste glejaka (GSC), komórki macierzyste białaczki (LSC) 


\section{INTRODUCTION}

$\mathrm{S}$ tem cells are undifferentiated and self-renewing, and have the potential to differentiate into different cell types/tissues. Stem cells are categorised based on their origin and potential functions. Embryonic stem cells (ESs) are pluripotent cells in the very early embryo which, during development, differentiate into specialised cells of different tissues ${ }^{(1)}$. In mammalian (and human) embryos, ESs are present in the inner mass of the blastocyst ${ }^{(2)}$. Tissue-specific stem cells, also called somatic or adult stem cells, are present in different organs and tissues. They have restricted potency in comparison to ESs, being able to differentiate only into the cell types of the tissue/organ they occupy. As such, they are the source of wear and tear, tissue repair, replacement, and regeneration ${ }^{(3)}$. Mesenchymal stem cells (MSCs) are present in the stroma (connective tissue) that surrounds tissues and organs. Their capabilities vary and depend on the place of their origin ${ }^{(4)}$. Induced pluripotent stem cells (iPSCs) are artificially created in the laboratory through the reprogramming of differentiated cells into embryonic-like stem cells ${ }^{(5-7)}$. The main sources of stem cells used in paediatric therapies are umbilical cord and umbilical cord blood, amniotic fluid, placenta, bone marrow, adipose tissue, urine, and iPSCs derived from the patient's cells ${ }^{(8-10)}$. Some of these findings have led to the development of cord blood banks that store umbilical cord blood which can be a source of haematopoietic cells for various therapies ${ }^{(11)}$ and new models for the therapeutic testing of paediatric cancers ${ }^{(12)}$.

Another, recently recognised, type of stem cells are cancer stem cells (CSCs), which are located within tumours. Because CSCs are tumourigenic when transplanted into another host, and resistant to conventional anticancer therapies, they are of special interest in the field of cancer therapies ${ }^{(13)}$. All these different types of stem cells, because of their amazing ability to differentiate into various cell types, replace damaged tissues and organs or promote tumour development, have become invaluable therapeutic tools or targets in different disciplines of modern medicine ${ }^{(14-17)}$. Because the current literature on stem cells is extremely vast, and exponentially growing, in this review, we will narrow the scope and give just some examples of the applications of stem cells or stem celltargeted therapies for the treatment of paediatric diseases.

\section{THERAPEUTIC APPLICATION OF MSCS IN PAEDIATRIC DISEASES}

The infants who were born prematurely and/or suffer from a chronic multifactorial disorder, hyaline membrane disease (HMD), and received oxygen therapies, may develop a chronic lung disease called bronchopulmonary dysplasia $(\mathrm{BPD})^{(18)}$. While the majority of patients recover, some are left with a long-term breathing problem ${ }^{(19-25)}$. Studies show that MSCs therapy is beneficial in the treatment of BPD in rodent models, where it promotes angiogenesis, improve alveolarisation and pulmonary hypertension ${ }^{(25-27)}$. Data from clinical trials in prematurely born infants at a risk of BPD and children with severe BPD have demonstrated that the umbilical cord-derived MSCs are beneficial ${ }^{(28-30)}$. Moreover, limited clinical data indicate that transplanted stem cells can be neuroprotective, and may decrease inflammatory injury in preterm neonates, neonatal stroke, and cerebral palsy ${ }^{(31)}$. However, some studies also show that there are certain subpopulations of MSCs which are myofibroblastic and increase inflammation ${ }^{(29)}$. Recent studies also indicate that there is a very pronounced effect of the gender of MSCs donor on the effectiveness of the MSCs in PBD therapies. Studies on newborn rats in the hyperoxia-induced PBD model found that the intratracheally applied BM-derived MSCs from female donors were much more effective in decreasing neonatal pulmonary hypertension and vascular remodelling than those from male donors, and showed increased expression of vascular endothelial growth factor (VEGF) and interleukin 10 (IL-10) as well as anti-inflammatory properties ${ }^{(25)}$.

There are also examples of the successful use of MSCs therapy in other areas of paediatrics, such as diabetes ${ }^{(9)}$, pulmonary and cardiac diseases ${ }^{(9,18,32,33)}$, reconstructive surgery and orthopaed $y^{(9,34,35)}$, transplantation, and graft-versushost diseases ${ }^{(9,36)}$. One of the examples involves the successful treatment of diabetes mellitus in adolescents aged 14 to 22 years ${ }^{(9,37)}$ with adipose-derived MSCs induced in vitro to produce insulin. Another example is that of a 21 -monthold child with the bone mineralisation disorder hypophosphatasia who was successfully treated (with the final assessment at 6 years of age) by intravenous delivery of MSCs derived from the sibling's bone marrow $^{(9,38)}$. A 9-year-old child with graft-versus-host disease developed after bone marrow transplantation was successfully treated (with the final assessment at $\sim 1$ year post-transplantation) with MSCs derived from the mother's bone marrow ${ }^{(9,39)}$. Several clinical trials in children with dilated cardiomyopathy (DCM) that causes paediatric heart failure, also showed a significant improvement of heart function after intramyocardial, intracoronary or peripheral administration of MSCs ${ }^{(9,40-43)}$. There is also a tremendous need for kidney, bladder and urethra regeneration therapies in children with congenital anomalies. Although there are positive experimental data from animal models, and some promising results of early clinical trials of bladder regeneration using a combination of stem cells and biomaterials in children with neurogenic bladder, which is a neurologic defect associated with spina bifida, so far there are no effective stem cell therapies in paediatric urology $\mathrm{y}^{(10,44,45)}$.

\section{CSCs - CHALLENGES AND POTENTIAL THERAPIES}

Brain cancer in children is one of the most malignant cancers and the leading cause of childhood mortality ${ }^{(46)}$. Among different cancer types, glioblastoma multiforme (GBM) is the most aggressive and deadly, with an average 
survival between 12 and 18 months $^{(47)}$. Radiation therapy and various chemotherapies, besides being highly neurotoxic for the developing child's brain ${ }^{(48)}$, are very ineffective because of the presence of CSCs that are resistant, multiply, and result in very aggressive secondary malignancies. CSCs have been shown to be present in various types of paediatric brain tumours including high-grade gliomas (HGGs) and medulloblastomas ${ }^{(49,50)}$. Paediatric HGGs show the presence of highly resistant glioma stem cells (GSCs), also called glioma initiation or progenitor cells ${ }^{(48)}$, and derived from different mutations ${ }^{(46)}$. In general, paediatric CSCs have different characteristics than adult CSCs. They differ not only in the expression of different markers but also have unique epigenetic modifications and are regulated by different signalling pathways driving self-renewal than adult CSCs (listed in Tab. 1 in Abou-Antoun et al., 2017(51)). A review of available therapies targeting CSCs suggests that the epigenetic and genetic approaches are the most promising in the treatment of paediatric brain tumours ${ }^{(46,51)}$. In addition, recent studies show a promising new treatment of paediatric HGGs based on targeting GSCs by the engineered herpes simplex virus (HSV) that is oncolytic for GSCs but harmless for normal cells ${ }^{(48)}$.

Similar considerations are probably also valid for the treatment of paediatric chronic myeloid leukaemia (CML). Recent studies demonstrate that there is a genetic difference between adult and paediatric CML driven by leukaemia stem cells (LSCs) derived from haematopoietic stem cells (HSCs) or committed progenitor cells ${ }^{(52)}$. The fusion gene $B C R-A B L 1$ that is present in the CML patients and codes for the chimeric protein with the constitutive tyrosine-kinase activity has a different distribution of breakpoints in paediatric CML than in adult $\mathrm{CML}^{(53,54)}$. This suggests that the $B C R-A B L 1$-dependent regulation of oncogenic properties and metastatic behaviour of LSCs, and thus the therapy, ought to be different in the adult and paediatric populations.

Another group of paediatric cancers with high mortality rates are tumours of the connective (mesenchymal or ectodermal) tissue, i.e. sarcomas. They are very heterogeneous, with over 50 known subtypes (listed in Tab. 1 in Dela Cruz, 2013 ${ }^{(55)}$ ). Recent studies have identified the presence of sarcoma-specific CSCs expressing several distinct markers: pentaspan transmembrane glycoprotein CD133, transmembrane tyrosine kinase growth factor receptor CD117, cell surface protein Stro-1, and human aldehyde hydrogenase $\mathrm{ALDH}^{(55)}$. These findings will contribute to the development of therapies targeting these particular cell populations in paediatric and adult sarcomas.

In summary, there is a tremendous need for further preclinical and clinical studies of existing and novel stem cell therapies, which may help to overcome existing obstacles such as, mentioning just a few, the ethical concerns associated with acquiring stem cells from human embryos, the real and potential tumourigenicity of stem cells, and the restricted proliferative and lineage potential of induced stem cells.

\section{Conflict of interest}

The authors do not report any financial or personal affiliations to persons or organisations that could adversely affect the content of or claim to have rights to this publication.

\section{Acknowledgements}

We are grateful for the support from the Polish Ministry of National Defence project "Kościuszko" \# 5508/2017/DA to JZK.

\section{References}

1. Evans MJ, Kaufman MH: Establishment in culture of pluripotential cells from mouse embryos. Nature 1981; 292: 154-156.

2. Thomson JA, Itskovitz-Eldor J, Shapiro SS et al.: Embryonic stem cell lines derived from human blastocysts. Science 1998; 282: 1145-1147.

3. Goodell MA, Nguyen H, Shroyer N: Somatic stem cell heterogeneity: diversity in the blood, skin and intestinal stem cell compartments. Nat Rev Mol Cell Biol 2015; 16: 299-309.

4. Rolandsson Enes S, Åhrman E, Palani A et al.: Quantitative proteomic characterization of lung-MSC and bone marrow-MSC using DIA-mass spectrometry. Sci Rep 2017; 7: 9316.

5. Durbin MD, Cadar AG, Chun YW et al.: Investigating pediatric disorders with induced pluripotent stem cells. Pediatr Res 2018; 84: 499-508.

6. Martin GR: Isolation of a pluripotent cell line from early mouse embryos cultured in medium conditioned by teratocarcinoma stem cells. Proc Natl Acad Sci U S A 1981; 78: 7634-7638.

7. Shimamoto R, Amano N, Ichisaka T et al.: Generation and characterization of induced pluripotent stem cells from aid-deficient mice. PLoS One 2014; 9: e94735.

8. Genova E, Cavion F, Lucafò M et al.: Induced pluripotent stem cells for therapy personalization in pediatric patients: focus on druginduced adverse events. World J Stem Cells 2019; 11: 1020-1044.

9. Nitkin CR, Bonfield TL: Concise review: mesenchymal stem cell therapy for pediatric disease: perspectives on success and potential improvements. Stem Cells Transl Med 2017; 6: 539-565.

10. Sharma S, Gupta DK: Tissue engineering and stem cell therapy in pediatric urology. J Indian Assoc Pediatr Surg 2019; 24: 237-246.

11. Thornley I, Eapen M, Sung L et al.: Private cord blood banking: experiences and views of pediatric hematopoietic cell transplantation physicians. Pediatrics 2009; 123: 1011-1017.

12. Bissig-Choisat $B$, Kettlun-Leyton $C$, Legras $X D$ et al.: Novel patient-derived xenograft and cell line models for therapeutic testing of pediatric liver cancer. J Hepatol 2016; 65: 325-333.

13. Yu Z, Pestell TG, Lisanti MP et al.: Cancer stem cells. Int J Biochem Cell Biol 2012; 44: 2144-2151.

14. Behnke J, Kremer S, Shahzad T et al.: MSC based therapies - new perspectives for the injured lung. J Clin Med 2020; 9: 682.

15. Hirschi KK, Li S, Roy K: Induced pluripotent stem cells for regenerative medicine. Annu Rev Biomed Eng 2014; 16: 277-294.

16. Lai P, Weng J, Guo L et al.: Novel insights into MSC-EVs therapy for immune diseases. Biomark Res 2019; 7: 6.

17. Okano H, Yamanaka S: iPS cell technologies: significance and applications to CNS regeneration and disease. Mol Brain 2014; 7: 22.

18. Thébaud B, Goss KN, Laughon M et al.: Bronchopulmonary dysplasia. Nat Rev Dis Primers 2019; 5: 78.

19. Bhandari A, McGrath-Morrow S: Long-term pulmonary outcomes of patients with bronchopulmonary dysplasia. Semin Perinatol 2013; 37: 132-137.

20. Bhandari A, Bhandari V: "New" bronchopulmonary dysplasia: a clinical review. Clin Pulm Med 2011; 18: 137-143.

21. Farstad T, Bratlid D, Medbø S et al.: Bronchopulmonary dysplasia - prevalence, severity and predictive factors in a national cohort of extremely premature infants. Acta Paediatr 2011; 100: 53-58. 
22. Jain D, Bancalari E: Bronchopulmonary dysplasia: clinical perspective. Birth Defects Res A Clin Mol Teratol 2014; 100: 134-144.

23. Jobe AH, Bancalari E: Bronchopulmonary dysplasia. Am J Respir Crit Care Med 2001; 163: 1723-1729.

24. Northway WH Jr, Rosan RC, Porter DY: Pulmonary disease following respirator therapy of hyaline-membrane disease. Bronchopulmonary dysplasia. N Engl J Med 1967; 276: 357-368.

25. Sammour I, Somashekar S, Huang J et al.: The effect of gender on mesenchymal stem cell (MSC) efficacy in neonatal hyperoxia-induced lung injury. PLoS One 2016; 11: e0164269.

26. Hansmann G, Fernandez-Gonzalez A, Aslam $M$ et al.: Mesenchymal stem cell-mediated reversal of bronchopulmonary dysplasia and associated pulmonary hypertension. Pulm Circ 2012; 2: $170-181$.

27. van Haaften $\mathrm{T}$, Byrne $\mathrm{R}$, Bonnet $\mathrm{S}$ et al.: Airway delivery of mesenchymal stem cells prevents arrested alveolar growth in neonatal lung injury in rats. Am J Respir Crit Care Med 2009; 180: 1131-1142.

28. Chang YS, Ahn SY, Yoo HS et al.: Mesenchymal stem cells for bronchopulmonary dysplasia: phase 1 dose-escalation clinical trial. J Pediatr 2014; 164: 966-972.e6.

29. Simones AA, Beisang DJ, Panoskaltsis-Mortari A et al.: Mesenchymal stem cells in the pathogenesis and treatment of bronchopulmonary dysplasia: a clinical review. Pediatr Res 2018; 83: 308-317.

30. Wu X, Xia Y, Zhou O et al.: Allogeneic human umbilical cordderived mesenchymal stem cells for severe bronchopulmonary dysplasia in children: study protocol for a randomized controlled trial (MSC-BPD trial). Trials 2020; 21: 125.

31. Yoshimoto M, Koenig JM: Stem cells: potential therapy for neonatal injury? Clin Perinatol 2015; 42: 597-612.

32. Bernstein HS, Srivastava D: Stem cell therapy for cardiac disease. Pediatr Res 2012; 71: 491-499.

33. Maxwell JT, Trac D, Shen M et al.: Electrical stimulation of pediatric cardiac-derived c-kit ${ }^{+}$progenitor cells improves retention and cardiac function in right ventricular heart failure. Stem Cells 2019; 37: 1528-1541.

34. Jakobsen C, Sørensen JA, Kassem M et al.: Mesenchymal stem cells in oral reconstructive surgery: a systematic review of the literature. J Oral Rehabil 2013; 40: 693-706.

35. Norambuena GA, Khoury M, Jorgensen C: Mesenchymal stem cells in osteoarticular pediatric diseases: an update. Pediatr Res 2012; 71: 452-458.

36. Amorin B, Alegretti AP, Valim V et al.: Mesenchymal stem cell therapy and acute graft-versus-host disease: a review. Hum Cell 2014; 27: 137-150.

37. Dave SD, Trivedi HL, Chooramani SG et al.: Management of type 1 diabetes mellitus using in vitro autologous adipose tissue transdifferentiated insulin-making cells. BMJ Case Rep 2013; 2013: bcr2013200226.
38. Whyte MP, Kurtzberg J, McAlister WH et al.: Marrow cell transplantation for infantile hypophosphatasia. J Bone Miner Res 2003; 18: 624-636.

39. Le Blanc K, Rasmusson I, Sundberg B et al.: Treatment of severe acute graft-versus-host disease with third party haploidentical mesenchymal stem cells. Lancet 2004; 363: 1439-1441.

40. Bergmane I, Lacis A, Lubaua I et al.: Follow-up of the patients after stem cell transplantation for pediatric dilated cardiomyopathy. Pediatr Transplant 2013; 17: 266-270.

41. Lacis A, Erglis A: Intramyocardial administration of autologous bone marrow mononuclear cells in a critically ill child with dilated cardiomyopathy. Cardiol Young 2011; 21: 110-112.

42. Olguntürk R, Kula S, Sucak GT et al.: Peripheric stem cell transplantation in children with dilated cardiomyopathy: preliminary report of first two cases. Pediatr Transplant 2010; 14: 257-260.

43. Rupp $\mathrm{S}$, Bauer J, Tonn $\mathrm{T}$ et al.: Intracoronary administration of autologous bone marrow-derived progenitor cells in a critically ill two-yr-old child with dilated cardiomyopathy. Pediatr Transplant 2009; 13: 620-623.

44. Panda A: Stem cell in urology - are we at the cusp of a new era? Transl Androl Urol 2018; 7: 653-658.

45. Soler R, Fullhase $C$, Atala A: Regenerative medicine strategies for treatment of neurogenic bladder. Therapy 2009; 6: 177-184.

46. Testa U, Castelli G, Pelosi E: Genetic abnormalities, clonal evolution, and cancer stem cells of brain tumors. Med Sci (Basel) 2018; 6: 85 .

47. Vigneswaran K, Neill S, Hadjipanayis CG: Beyond the World Health Organization grading of infiltrating gliomas: advances in the molecular genetics of glioma classification. Ann Transl Med 2015; 3: 95.

48. Friedman GK, Raborn J, Kelly VM et al.: Pediatric glioma stem cells: biologic strategies for oncolytic HSV virotherapy. Front Oncol 2013; 3: 28.

49. Singh SK, Clarke ID, Terasaki $M$ et al.: Identification of a cancer stem cell in human brain tumors. Cancer Res 2003; 63: 5821-5828.

50. Singh SK, Clarke ID, Hide T et al.: Cancer stem cells in nervous system tumors. Oncogene 2004; 23: 7267-7273.

51. Abou-Antoun TJ, Hale JS, Lathia JD et al: Brain cancer stem cells in adults and children: cell biology and therapeutic implications. Neurotherapeutics 2017; 14: 372-384.

52. Passegué E, Weisman IL: Leukemic stem cells: where do they come from? Stem Cell Rev 2005; 1: 181-188.

53. Houshmand M, Simonetti G, Circosta $P$ et al.: Chronic myeloid leukemia stem cells. Leukemia 2019; 33: 1543-1556.

54. Hijiya N, Schultz KR, Metzler M et al.: Pediatric chronic myeloid leukemia is a unique disease that requires a different approach. Blood 2016; 127: 392-399.

55. Dela Cruz FS: Cancer stem cells in pediatric sarcomas. Front Oncol 2013; 3: 168. 